\title{
Seasonal dynamics in taxonomy and function within bacterial and viral metagenomic assemblages recovered from a freshwater agricultural pond
}

Jessica Chopyk ${ }^{1,2^{*}}$ (D, Daniel J. Nasko ${ }^{3}$, Sarah Allard ${ }^{1}$, Anthony Bui ${ }^{1}$, Mihai Pop ${ }^{3}$, Emmanuel F. Mongodin ${ }^{4}$ and Amy R. Sapkota ${ }^{1}$

\begin{abstract}
Background: Ponds are important freshwater habitats that support both human and environmental activities. However, relative to their larger counterparts (e.g. rivers, lakes), ponds are understudied, especially with regard to their microbial communities. Our study aimed to fill this knowledge gap by using culture-independent, highthroughput sequencing to assess the dynamics, taxonomy, and functionality of bacterial and viral communities in a freshwater agricultural pond.

Results: Water samples $(n=14)$ were collected from a Mid-Atlantic agricultural pond between June 2017 and May 2018 and filtered sequentially through 1 and $0.2 \mu \mathrm{m}$ filter membranes. Total DNA was then extracted from each filter, pooled, and subjected to 16S rRNA gene and shotgun sequencing on the Illumina HiSeq 2500 platform. Additionally, on eight occasions water filtrates were processed for viral metagenomes (viromes) using chemical concentration and then shotgun sequenced. A ubiquitous freshwater phylum, Proteobacteria was abundant at all sampling dates throughout the year. However, environmental characteristics appeared to drive the structure of the community. For instance, the abundance of Cyanobacteria (e.g. Nostoc) increased with rising water temperatures, while a storm event appeared to trigger an increase in overall bacterial diversity, as well as the relative abundance of Bacteroidetes. This event was also associated with an increase in the number of antibiotic resistance genes. The viral fractions were dominated by dsDNA of the order Caudovirales, namely Siphoviridae and Myovirdae.
\end{abstract}

Conclusions: Overall, this study provides one of the largest datasets on pond water microbial ecology to date, revealing seasonal trends in the microbial taxonomic composition and functional potential.

Keywords: Metagenome, Shotgun, Agricultural irrigation, Antibiotic resistance, Microbial communities, Bacteria, Bacteriophage

\footnotetext{
* Correspondence: jchopyk@ucsd.edu

${ }^{1}$ Maryland Institute for Applied Environmental Health, University of Maryland

School of Public Health, College Park, MD, USA

${ }^{2}$ Department of Pathology University of California San Diego, La Jolla,

California, USA

Full list of author information is available at the end of the article
}

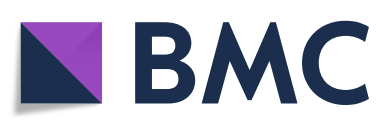

(c) The Author(s). 2020 Open Access This article is licensed under a Creative Commons Attribution 4.0 International License, which permits use, sharing, adaptation, distribution and reproduction in any medium or format, as long as you give appropriate credit to the original author(s) and the source, provide a link to the Creative Commons licence, and indicate if changes were made. The images or other third party material in this article are included in the article's Creative Commons licence, unless indicated otherwise in a credit line to the material. If material is not included in the article's Creative Commons licence and your intended use is not permitted by statutory regulation or exceeds the permitted use, you will need to obtain permission directly from the copyright holder. To view a copy of this licence, visit http://creativecommons.org/licenses/by/4.0/. The Creative Commons Public Domain Dedication waiver (http://creativecommons.org/publicdomain/zero/1.0/) applies to the data made available in this article, unless otherwise stated in a credit line to the data. 


\section{Background}

Ponds are small $\left(1 \mathrm{~m}^{2}\right.$ to $\left.\sim 50,000 \mathrm{~m}^{2}\right)$, shallow, standing water bodies that are found ubiquitously among Earth's terrestrial biomes, with an estimated 2.6 to 9 million ponds located within the U.S. alone [1, 2]. Globally, ponds occupy a greater total area than lakes and are considered to be functionally and ecologically distinct, playing a major role in the global cycling of carbon and supporting a high level of macro- and micro- species diversity [1-6]. Along with those that are formed by natural processes, there are many ponds that are human constructed for a variety of recreational, industrial, agricultural, and aesthetic purposes [1,7]. For instance, in areas where municipal and ground water sources are limited or unavailable, ponds are built to capture and store water for irrigation $[8,9]$. Despite the importance of ponds to both environmental and human activities, the majority of research on freshwater resources is focused on large water systems (e.g. lakes). As a result, outside of extreme environments (e.g. saline/hypersaline [10-12], thermokarsts [13]), and aquaculture facilities [14-16] ponds remain largely understudied [17], especially with regard to their microbial communities.

Microbial communities are vital to the health and maintenance of aquatic ecosystems [18]. However, due to their topography (e.g. size small and shallow depth) ponds are uniquely sensitive to anthropogenic and environmental factors [19]. Nonpoint source nutrient pollution, coupled with warm temperatures, and long water residence times can result in a high abundance of algal and cyanobacterial concentrations, in some cases leading to blooms that deplete oxygen levels and produce toxins [20-23]. Storm events can also trigger an influx of fecal pathogens that can contaminate irrigation supplies and subsequently crops [24-26]. For instance, a 2002 multistate outbreak of Salmonella Newport on tomatoes was traced back to contaminated pond water used for irrigation [27]. In addition to pathogens, runoff can introduce pollutants originating from land use practices (e.g. antibiotics, pesticides) [28]. Because of the long water retention times of ponds, these pollutants may then diffuse and accumulate, leading in some cases to changes in bacterial community dynamics, including increased selection pressures for antibiotic-resistant bacterial populations [29]. However, the persistence of these disruptions and foreign bacterial agents depends on complex factors such as sedimentation, temperature, UV light, and predation [30].

Despite the value in surveying the microbial composition of ponds, the limited collection of previous studies have been largely restricted to PCR or culture-based methodologies and often comprise just a static "snap shot" of the microbial community. Thus, we are restricted in our understanding of microbial functionality, dynamics, and response under multiple conditions. Shotgun metagenomics makes it possible to observe and analyze a broad sampling of microbial diversity without cultivation, providing new insights into their genomic complexity and functional potential [31]. In addition, because shotgun metagenomic sequencing does not rely on a universally distributed marker gene, such as the $16 \mathrm{~S}$ rRNA gene, it can also be used to explore the viral community [32].

Using metagenomics previous studies have identified that within the viral community of surface freshwater sites bacteriophages (phage) dominate [33-37]. Phages are critical components in shaping the evolution, diversity, abundance, and genetic composition of bacteria [38]. Temperate phages (forming prophage) can influence their hosts' phenotype through the horizontal transfer of genes, such as those for antibiotic resistance/ toxins and those that promote host fitness and adaptability [39, 40]. However, phage composition, diversity, and host-interactions are often linked to fluctuating environmental characteristics [41]. Therefore, assessing phage ecology and relationships with their host(s) is critical with regard to completing a comprehensive characterization of pond biodiversity.

In the present study, we periodically sampled surface water from a freshwater agricultural pond located in the Mid Atlantic, United States. From these samples, we employed culture-independent high-throughput sequencing to characterize the dynamics, taxonomy, and functionality of their bacterial and viral communities over time.

\section{Materials and methods}

\section{Study site and sample collection}

Water samples (total $n=14$ ) were collected on the following dates: 6/12/17, 7/17/17, 8/8/17, 8/21/17, 9/11/17, 9/25/17, 10/30/17, 11/13/17, 12/18/17, 1/22/18, 2/12/18, $3 / 12 / 18,4 / 9 / 18$, and $5 / 7 / 18$ from a freshwater agricultural pond located in a rural area of central Maryland, United States (maximum depth of ca. $3.35 \mathrm{~m}$ and a surface area of ca. $0.26 \mathrm{ha}$ ). At each date, a utility transfer pump (0.08 W; Everbilt, Atlanta, GA) powered by a EU1000i generator (American Honda Motor Co., Ltd., Alpharetta, GA) and connected to a sampling cartridge via vinyl braided tubing $(1.9 \mathrm{~cm}$ inner diameter, Sioux Chief, Peculiar, MO) was submerged $15-30 \mathrm{~cm}$ below the surface and used to pump roughly $10 \mathrm{~L}$ of water into a sterile polypropylene carboy. Samples were kept in the dark at $4{ }^{\circ} \mathrm{C}$ and processed within $24 \mathrm{~h}$ of collection.

\section{Water physicochemical assessment}

At each time point a ProDSS digital sampling system (YSI, Yellow Springs, OH, United States) was used to measure the following physicochemical properties of the 
pond water: temperature $\left({ }^{\circ} \mathrm{C}\right), \mathrm{pH}$, dissolved oxygen $(\%$ $\mathrm{DO})$, conductivity $(\mathrm{SPC} \mathrm{uS} / \mathrm{cm})$, oxidation-reduction potential (ORP, mv), turbidity (FNU), nitrate $(\mathrm{mg} / \mathrm{L})$, and chloride $(\mathrm{mg} / \mathrm{L})$. Using the Nation Weather Services historical data archive, ambient temperature was recorded for the time and date at each sampling event.

\section{Water sample processing}

Microbial DNA was isolated as described in detail previously [6]. Briefly, for each sample $10 \mathrm{~L}$ of water was filtered sequentially through a Whatman $1 \mu \mathrm{m}$ polycarbonate filter (Sigma-Aldrich, MO, United States) and a $142-\mathrm{mm}$ diameter $0.2 \mu \mathrm{m}$ membrane filter (Pall Gelman Sciences, MI, United States) attached via sterile $1.6 \mathrm{~mm}$ PVC tubing with a Watson Marlow 323 Series Peristaltic Pump (Watson-Marlow, Falmouth, Cornwall, United Kingdom).

The $1 \mu \mathrm{m}$ polycarbonate filter was used initially to collect large cells and debris to make the subsequent $0.2 \mu \mathrm{m}$ membrane filtration more effective and efficient. Following filtration, filters $(1$ and $0.2 \mu \mathrm{m})$ containing the cellular fraction were dissected into four equal quadrants and stored at $-80^{\circ} \mathrm{C}$ until DNA extraction.

\section{Viral concentration and DNA extraction}

On 6/12/17, 7/17/17, 8/8/17, 8/21/17, 9/11/17, 9/25/ $17,10 / 30 / 17$, and $5 / 7 / 18$ the iron chloride procedure was used on the pond water after sequential $1 \mu \mathrm{m}$ and $0.2 \mu \mathrm{m}$ filtration, with the $0.2 \mu \mathrm{m}$ a common pore size used in virome generation to prevent cellular contamination [33, 37, 42]. A $1 \mathrm{~mL}$ solution of $\mathrm{FeCl}_{3}$ (4.83 $\mathrm{g} \mathrm{FeCl}_{3}$ into $100 \mathrm{ml} \mathrm{H}_{2} \mathrm{O}$ ) was added to the filtered pond water and incubated in the dark for $1 \mathrm{~h}$. The samples were then filtered onto 142-mm $1 \mu \mathrm{m}$ polycarbonate filters (Sigma-Aldrich, MO, United States) to capture flocculated viral particles [43]. Filters were stored at $4{ }^{\circ} \mathrm{C}$ in the dark until resuspension. For resuspension, filters were rocked overnight at $4{ }^{\circ} \mathrm{C}$ in $10 \mathrm{~mL}$ of $0.1 \mathrm{M}$ EDTA - $0.2 \mathrm{M} \mathrm{MgCl}_{2-} 0.2$ $\mathrm{M}$ Ascorbate Buffer, described in detail elsewhere [43]. Resuspended viral particles were then subjected to a DNase I (Sigma-Aldrich, MO, United States) treatment for $1 \mathrm{~h}$ and passed through a 33-mm diameter sterile syringe filter with a $0.2 \mu \mathrm{m}$ pore size (Millipore Corporation, MA, United States). DNA was extracted from $500 \mu \mathrm{l}$ of the viral concentrate using the AllPrep PowerViral DNA/RNA Kit (Qiagen, CA, United States) per the manufacturer's instructions. Prior to sequencing, viral DNA was tested for the presence of bacterial contamination via 16S rRNA gene PCR.

\section{Microbial DNA extraction}

Microbial DNA was extracted from the filters using an enzymatic and mechanical lysis procedure $[6,44]$. Each filter quadrant was placed in a lysing matrix tube with a cocktail of PBS buffer, lysozyme, lysostaphin, and mutanolysin. After incubation at $37^{\circ} \mathrm{C}$ for $30 \mathrm{~min}$, a second lysing cocktail (Proteinase $\mathrm{K}$ and SDS) was added followed by another incubation at $55^{\circ} \mathrm{C}$ for $45 \mathrm{~min}$ and mechanical lysis via bead beating with a FastPrep Instrument FP-24 (MP Biomedicals, CA) $(6.0 \mathrm{~m} / \mathrm{s}$ for $40 \mathrm{~s})$. The resulting DNA was purified with the QIAmp DNA mini kit (Qiagen, CA, USA) and assessed for quality with the NanoDrop 2000 Spectrophotometer. To create a composite sample, microbial DNA extracts from all four quadrants of both filter sizes were pooled for each date.

\section{S rRNA gene sequencing and analysis}

From each of the pooled microbial DNA extractions $(n=14)$, the V3-V4 hypervariable region of the $16 \mathrm{~S}$ rRNA gene was PCR-amplified and sequenced on the Illumina HiSeq 2500 (Illumina, San Diego, CA, United States) utilizing a dual-indexing strategy for multiplexed sequencing developed at the Institute for Genome Sciences [45].

The resulting $16 \mathrm{~S}$ rRNA reads were screened for low quality bases and short read lengths, merged with PAND Aseq, de-multiplexed, and trimmed of artificial barcodes and primers [46-48]. Using VSEARCH, reads were then checked for chimeras with the UCHIME algorithm and the ChimeraSlayer RDPGold_Trainset reference training dataset [49]. Chimera-free reads were then clustered de novo into Operational Taxonomic Units (OTUs) using VSEARCH with a minimum confidence threshold of 0.97. Following OTU clustering, alpha diversity (Observed OTUs) was calculated and assessed using the $\mathrm{R}$ packages: Bioconductor [50], metagenomeSeq [51], vegan [52], phyloseq [53], fossil [54], biomformat [53], and ggplot2 [55] on unrarefied data and data rarefied to an even sampling depth (13,956 sequences). Taxonomic assignments via $16 \mathrm{~S}$ rRNA were not considered in this study.

\section{Shotgun sequencing for microbial metagenomes and viromes}

For both the microbial $(n=14)$ and viral $(n=8)$ samples, DNA extracts were shotgun sequenced. Briefly, for each sample DNA was used in a tagmentation reaction, followed by 12 cycles of PCR amplification using Nextera i7 \& i5 index primers per the modified Nextera XT protocol. The final libraries were then quantitated by Quant-iT hsDNA kit. The libraries were pooled, loaded onto an Agilent High Sensitivity D1000 ScreenTape System, and then sequenced on an Illumina 2500 Hiseq 
X10 flow cell (Illumina, San Diego, CA, United States) targeting 100 bp paired-end reads per sample.

\section{Microbial and viral metagenomic assembly}

After sequencing the paired-end reads from both microbial and viral libraries were quality trimmed using Trimmomatic ver. 0.36 (sliding window:4:30 min len:60) [56]. The quality reads were then merged with FLASh ver. 1.2.11 [57] and assembled de novo with MEGAHIT [58]. Open reading frames (ORFs) were predicted and translated from each library using MetaGene [59].

Microbial and viral taxonomic and functional classification For the microbial metagenomes, translated peptide ORFs were searched against UniRef 100 (retrieved May 2018) via protein-protein BLAST (BLASTp ver. 2.6.0+) (E value $\leq 1 \mathrm{e}-3)[60,61]$. Max cumulative bit score was used to assign taxonomy and calculated by summing the bit scores of all taxa with a hit to a translate peptide ORFs encoded by the contig. Translated peptide ORFs were also searched against the SEED database using BLASTp (E value $\leq 1 \mathrm{e}-3$ ). Translated peptide ORFs were assigned to a SEED subsystem with the maximum sum bit score among all of the ORF's hits. Taxonomic and functional classification of viromes were conducted as described in Chopyk et al., 2017 [6].

For both viral and microbial metagenomes coverage was calculated for each contig by recruiting qualitycontrolled reads to assembled contigs via Bowtie 2 ver. 2.3.3 in very sensitive local mode. Then using the "depth" function in Samtools ver. 1.4.1 we computed the per-contig coverage [62]. Coverage for translated peptide ORFs were denoted by start and stop coordinates within each contig. To normalize abundances across libraries, contig and ORF coverages were divided by the sum of coverage per million, similar to the transcripts per million (TPM) metric used in RNA-Seq [63, 64]. Scripts performing these assignments and normalization are available at https://github.com/dnasko/baby_virome. All taxonomic and functional data were visualized using the $\mathrm{R}$ packages ggplot2 ver. 3.1.0 and pheatmap ver 1.0.10 $[55,65]$.

\section{ARGs prediction and host assignment}

Translated peptide ORFs from both viral and microbial metagenomes were searched against the "Comprehensive Antibiotic Resistance Database" (CARD; retrieved July 2018) via protein-protein BLAST (BLASTp ver. 2.6.0+) (E value $\leq 1 \mathrm{e}-3)[60,66]$. A queried translated peptide ORF was considered an ARG if it had $>40 \%$ coverage and > $80 \%$ amino-acid identity to a CARD protein $[67,68]$. In addition, for the ARGs conferring resistance through target mutations, a post-processing step was taken to confirm the presence of resistance-conferring mutations; a
MAFFT alignment with reference sequences available at CARD [69]. Taxonomic assignments were parsed for contigs containing ARG-like translated peptide ORFs. Networks were visualized by Cytoscape [70].

\section{Statistical analysis}

Significance tests were conducted using an ANOVA with post hoc Tukey's HSD Test among meteorological seasons, defined by the American Meteorological Society. Additionally, to identify associations between the water physicochemical characteristics and the normalized abundance of the bacterial genera, as well as between the abundance of bacterial genera and viral families, Pearson's correlation coefficients were calculated in RStudio version 1.0.153 and corrected for multiple comparisons with FDR.

\section{Results}

Sequencing effort and assembly

All samples $(n=22)$ were sequenced on the Illumina HiSeq, 14 microbial and eight viral. In total, there were $907,056,944$ read pairs for the microbial metagenomes with an average of $64,789,782$ read pairs per metagenome (+/- 7,936,115 Standard Deviation, SD) (Table S1). For the viral metagenomes, there were 489,222,408 read pairs with an average of 61,152,801 read pairs per metagenome (+/-9,064,079 SD) (Table S2). After assembly, there were a total of 9,979,705 contigs generated, with an average of 712,836 contigs per sample $(+/-142,125$ SD) for the microbial metagenomes and a total of 1,913, 254 contigs, with an average of 239,157 contigs per sample $(+/-45,658 \mathrm{SD})$ for the viromes.

\section{Temporal variations in physicochemical characteristics and bacterial diversity of pond water}

Physicochemical variables for each sampling date are shown in Fig. 1. Water temperature ranged from $29^{\circ} \mathrm{C}$ $(7 / 17 / 17)$ to $4{ }^{\circ} \mathrm{C}(1 / 22 / 18)$. By meteorological season, winter $(12 / 18 / 17,1 / 22 / 18,2 / 12 / 18)$ had an average water temperature of $6{ }^{\circ} \mathrm{C}$. This was significantly $(p \leq$ $0.05)$ lower than autumn $(9 / 11 / 17,9 / 25 / 17,10 / 30 / 17$, $11 / 13 / 17)$ and summer $(6 / 12 / 17,7 / 17 / 17,8 / 8 / 17,8 / 21 /$ 17), which had an average water temperature of $18^{\circ} \mathrm{C}$ and $27^{\circ} \mathrm{C}$, respectively. In addition, the water temperature in summer was significantly $(p \leq 0.05)$ higher than spring $(3 / 12 / 18,4 / 9 / 18,5 / 7 / 18)$. The only other environmental factor that significantly $(p \leq 0.05)$ differed by meteorological season was ORP, which was significantly higher in spring compared to autumn. Precipitation 24-h prior to sampling occurred only on $8 / 8$ / $17,10 / 30 / 17$, and $2 / 12 / 18$.

Furthermore, we examined the bacterial diversity at each time point by way of amplification and sequencing of the $16 \mathrm{~S}$ rRNA gene. Overall, the alpha diversity, 


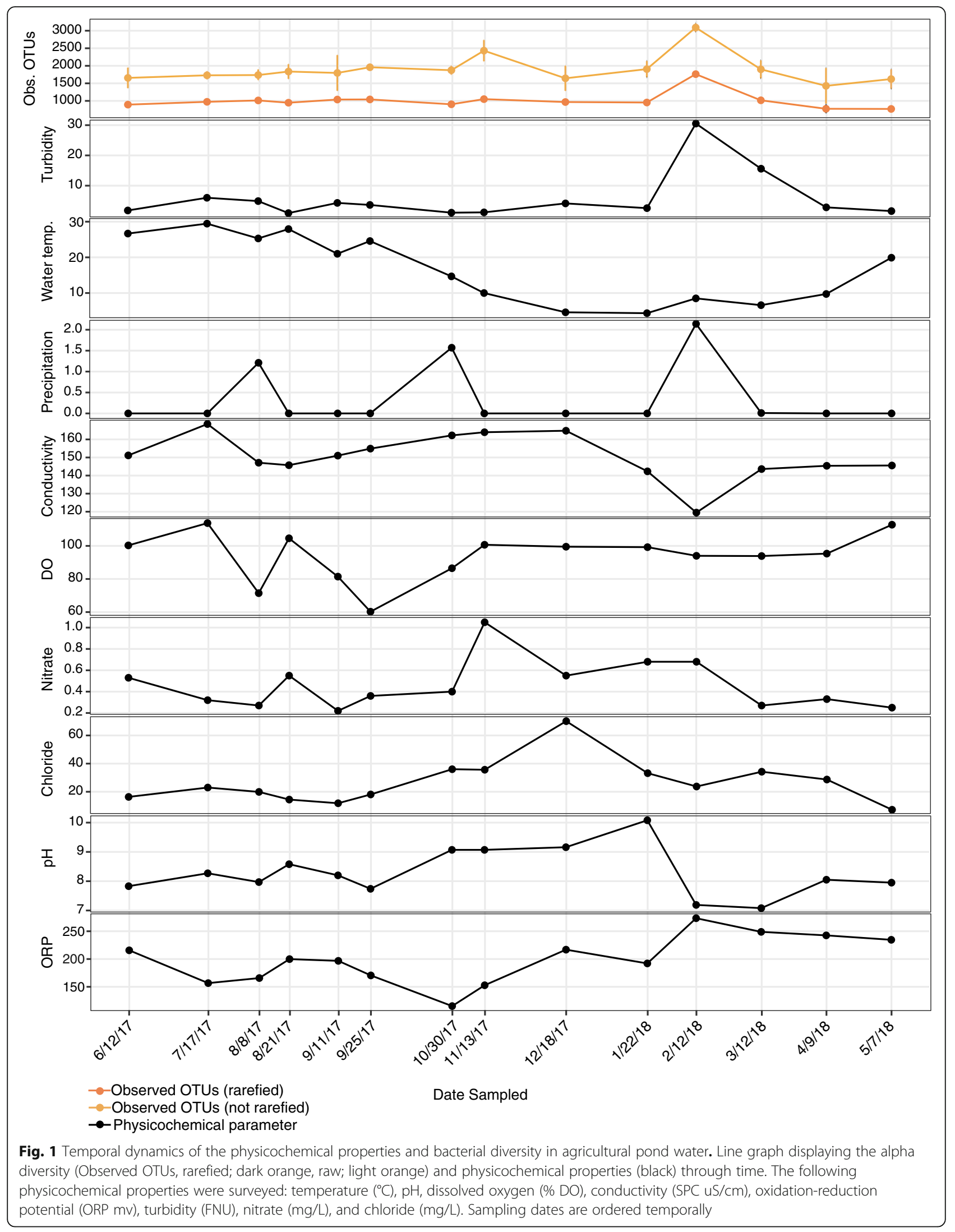


surveyed by rarefied and unrarefied Observed OTUs, was generally steady throughout the year, with no significant differences found between rarefied or unrarefied diversity and meteorological season. However, by physicochemical parameter we did find some correlations. Specifically, we found that turbidity was significantly $(p \leq 0.05)$ positively correlated with the abundance of rarefied and unrarefied Observed OTUs.

\section{Temporal variations in bacterial phyla of pond water}

For the microbial metagenomes collected throughout the year, on average $78 \%(+/-4 \% \mathrm{SD})$ of contigs could be assigned a taxonomic representative (Table S3). Of these, the majority was homologous to Bacteria 93\% $(+/-2 \% \mathrm{SD})$, followed by Eukaryota $3 \%(+/-1 \% \mathrm{SD})$, and Viruses 3\% (+/-0.5\% SD).

For each of the contigs, a normalized abundance was calculated to account for assembly proficiency and sequencing depth and then parsed for those assigned as Bacteria. Of these, the most frequently observed bacterial phylum was Proteobacteria, which accounted for $43 \%$ $(+/-5 \%)$ of the total bacterial assigned abundance across all time points (Fig. 2). The next most abundant phyla were Actinobacteria at $28 \%(+/-8 \%)$, Bacteroidetes at $12 \%$ $(+/-4 \% \mathrm{SD})$, and Firmicutes at $7 \%(+/-1 \%)$. The largest phylum, Proteobacteria, was composed chiefly of the class Betaproteobacteria 50\% (+/-6\% SD) and Alphaproteobacteria 23\% (+/-5\% SD), with the largest spike in Alphaproteobacteria occurring on 2/12/18.

By meteorological season, winter had a significantly $(p \leq 0.05)$ higher abundance of Bacteroidetes than all other seasons, while summer had a significantly $(p \leq$ 0.05) higher abundance of Cyanobacteria compared to all other seasons. Summer and autumn both had a high abundance of Firmicutes, with both significantly ( $p \leq$ $0.05)$ higher than spring and winter.

In addition to differences by meteorological season, the normalized abundance of some of these top phyla correlated with physicochemical parameters surveyed in the water: Actinobacteria $(\mathrm{R}=0.65, p \leq$ $0.05)$ correlated with conductivity, Bacteroidetes correlated with precipitation $(\mathrm{R}=0.63, p \leq 0.05)$, conductivity $(\mathrm{R}=-0.67, p \leq 0.05)$, and turbidity $(\mathrm{R}=0.74$, $p \leq 0.05$ ), and Chloroflexi correlated negatively with

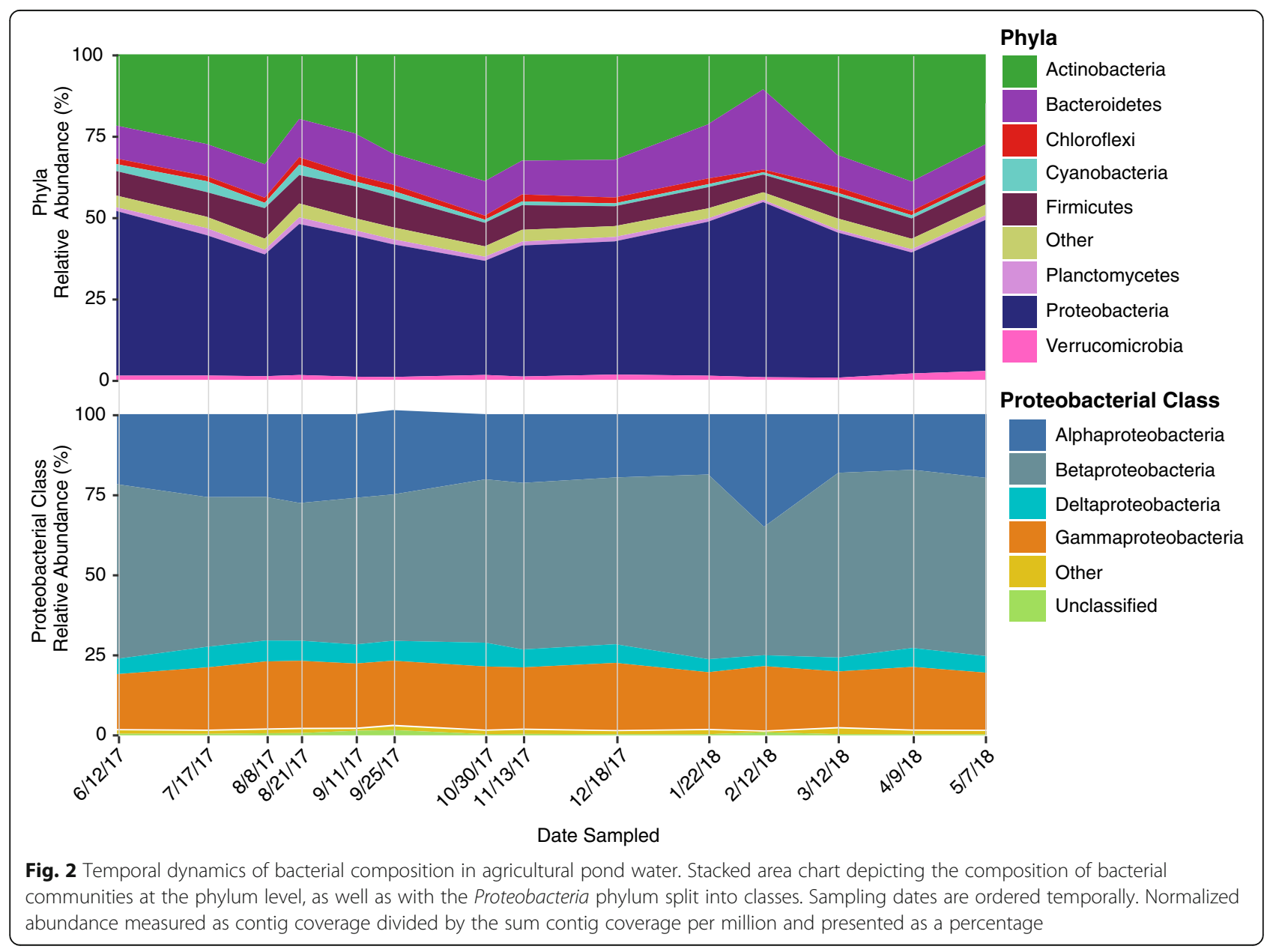




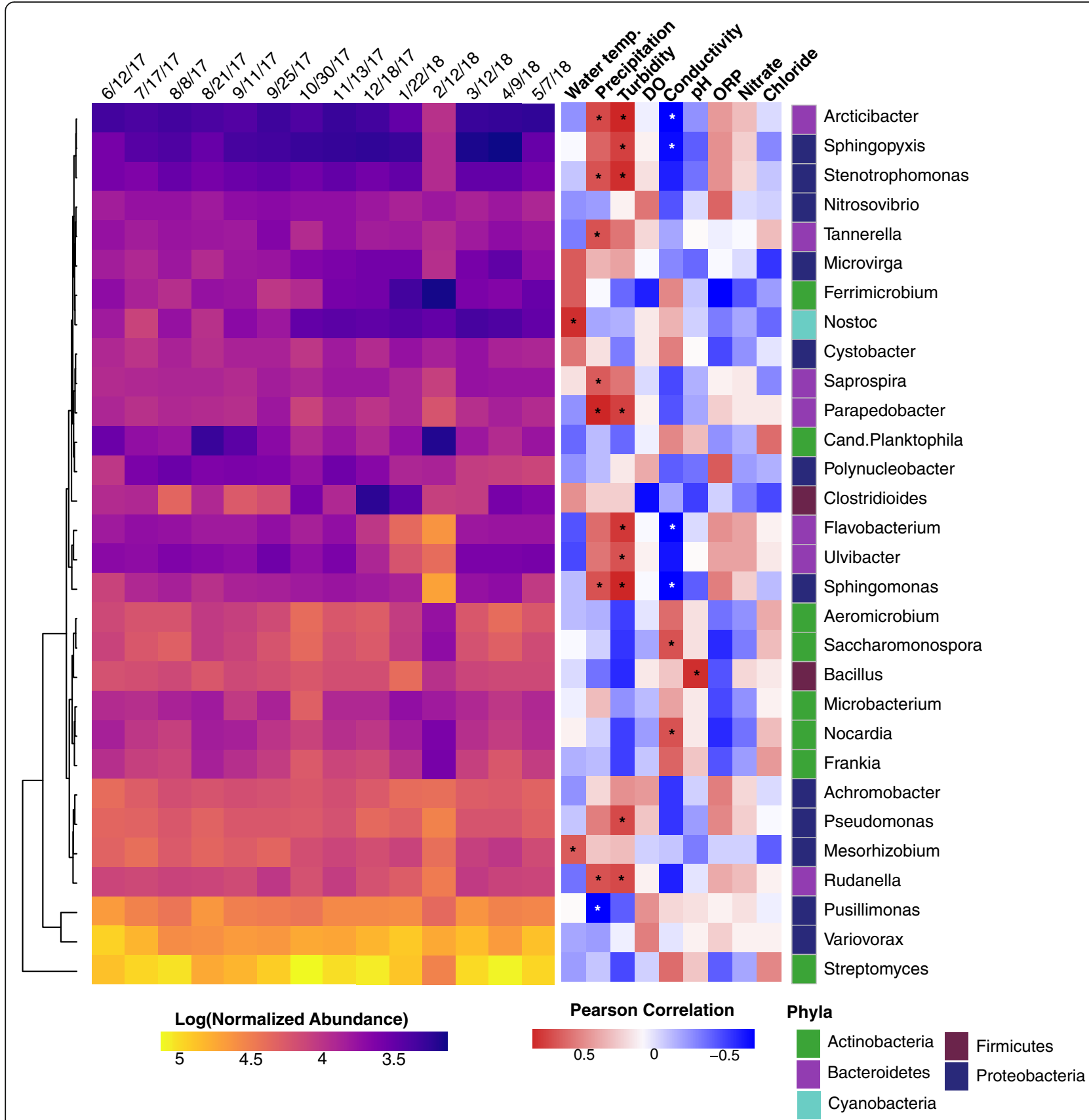

Fig. 3 Bacterial genera and correlations with physicochemical factors in agricultural pond water across sampling dates. Heatmaps based on the log-transformed normalized abundance of the most dominant genera (> 1\% in at least one sample) and the Pearson's correlation coefficients between the water physicochemical factors and the bacterial genera normalized abundance listed on the Y-axis. Genera annotated with colors representative of their phylum (Proteobacteria: dark blue, Actinobacteria: green, Firmicutes: burgundy, Bacteriodetes: purple, Cyanobacteria: light blue). Hierarchical clustering of genera was performed using the complete clustering method with Euclidean distances on the bacterial abundances. Sampling dates ordered temporally. Asterix denote significant Pearson correlations $(p \leq 0.05)$ after FDR correction. Normalized abundance measured as contig coverage divided by the sum contig coverage per million

precipitation $(\mathrm{R}=-0.68, p \leq 0.05)$ and turbidity $(\mathrm{R}=-$ $0.63, p \leq 0.05)$. Additionally, Cyanobacteria $(\mathrm{R}=0.83$, $p \leq 0.01)$, Firmicutes $(\mathrm{R}=0.80, p \leq 0.01)$, and Planctomycetes $(\mathrm{R}=0.74, p \leq 0.01)$ all correlated positively with water temperature.
Temporal variations in bacterial genera of pond water

Within the bacterial assignments classified at the genera level, Streptomyces (11\% +/-3\% SD), Variovorax (7\% $+/-2 \%$ SD), Pusillimonas (4\% +/- 1\% SD), and Pseudomonas $(3 \%+1-0.5 \%$ SD) were the most abundant 
(Fig. 3). By meteorological season, winter had a significantly $(p \leq 0.05)$ higher abundance of Ulvibacter, Rudanella, and Flavobacterium compared to all seasons. Spring had a significantly $(p \leq 0.05)$ higher abundance of Polynucleobacter compared to all seasons and a significantly higher abundance of Nitrosovibrio compared to autumn. Summer had a significantly $(p \leq 0.05)$ higher abundance of Nostoc compared to all seasons. Autumn had a significantly $(p \leq 0.05)$ higher abundance of Ferrimicrobium compared to winter.

Similar to the analysis of the bacterial phyla, we calculated Pearson's correlations between the normalized abundance of the dominant bacterial genera and the physicochemical parameters of the pond water (Fig. 3). In total, precipitation and turbidity correlated with the greatest number of genera, followed by conductivity and water temperature.

\section{Microbial metagenome, functional potential}

On average, $40 \%(+/-3 \%)$ of translated peptide ORFs from the microbial metagenomes could be assigned a SEED functional category (Fig. 4). Of these, "Carbohydrate Metabolism" was the most abundant representing on average $16 \%(+/-1 \%)$ of the total assigned functional abundance followed by "Amino Acids and Derivatives" at $12 \%(+/-0.3 \%)$, "Protein Metabolism" at $9 \%(+/-0.4 \%)$, and either "Cofactors, Vitamins, Prosthetic Groups, Pigments" at $7 \%(+/-0.2 \%)$ or "DNA Metabolism" at 6\% (+/-0.5\%). By meteorological season, the only SEED functional category that was significantly $(p \leq 0.05)$ different among seasons was "Motility and Chemotaxis", which was significantly higher in winter compared to autumn and summer.

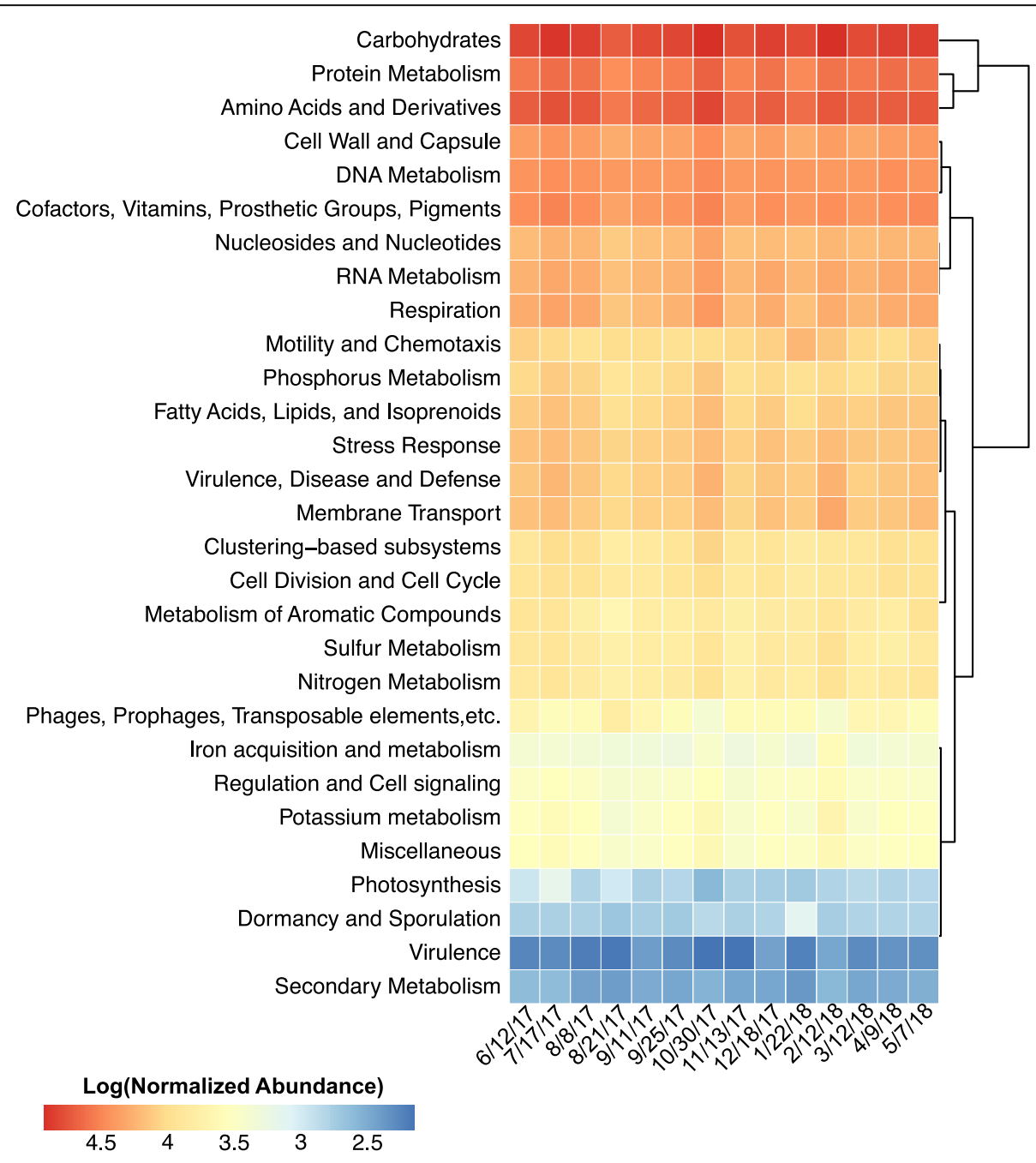

Fig. 4 Functional composition in agricultural pond water across sampling dates. Heatmap of the microbial metagenomes' functional profiles, represented by the SEED systems, at each sampling date. Hierarchical clustering of SEED systems was performed using the complete clustering method with Euclidean distances. Sampling dates are ordered temporally. Normalized abundance measured as ORF coverage divided by the sum ORF coverage per million 
Similar to the bacterial abundance, precipitation was significantly correlated with the abundance of a diversity of functional SEED systems including: "Potassium metabolism" $(\mathrm{R}=0.78, p \leq 0.001)$, "Regulation and Cell signaling" $(\mathrm{R}=0.76, \quad p \leq 0.01)$, "Iron acquisition and metabolism" ( $\mathrm{R}=0.74, p \leq 0.01)$, "Virulence Disease and Defense" ( $\mathrm{R}=0.72, p \leq 0.01)$, "Miscellaneous" $(\mathrm{R}=0.69$, $p \leq 0.01)$, "Phages Prophages Transposable elements etc." $(\mathrm{R}=-0.69, p \leq 0.05)$, "Carbohydrates" $(\mathrm{R}=0.68, p \leq 0.05)$, and "Membrane Transport" ( $\mathrm{R}=0.67, p \leq 0.01)$. Likewise, turbidity was also correlated with "Iron acquisition and metabolism" ( $\mathrm{R}=0.76, p \leq 0.01)$.

\section{Antibiotic resistance and host taxonomy in pond water}

To assess antibiotic resistance in the microbial and viral metagenomes, we conducted a BLAST analysis of translated peptide ORFs against CARD. No translated peptide ORFs within the viral metagenomes had significant homology to ARGs within CARD. However, in the microbial metagenomes, 184 translated peptide ORFs were identified as 21 unique ARGs conferring resistance to over 15 drug classes (Fig. 5). For the ARGs whose resistance is associated with target mutations, they were confirmed to carry the following mutations: $r p s L$; K88R [71]; gyrA, S95T [72]; murA C117D [73]; rpoB H526T [74]; EF-Tu Q124K [75]; ndh V300G, V246A [76]. A normalized abundance was also calculated for each ARG-like translated peptide ORF. From this, the greatest abundance of ARG-like translated peptide ORFs was attributed to the sampled collected on $10 / 30 / 17$, followed by $9 / 25 / 17$ and $9 / 11 / 17$. However, the greatest diversity of ARGs was identified on 2/12/18.

For each ARG-like translated peptide ORF, the source genus and phylum were parsed (Fig. 6). All the ARG-like translated peptide ORFs originated from contigs assigned as Bacteria. Of these, $71 \%$ of were contigs assigned to the phylum Actinobacteria (9 unique ARGs), largely of the genus Ferrimicrobium (30 rpsL), Saccharomonospora (1 RbpA, 4 gyrA, 12 mtrA, 4 murA, 2 rpsL), and Aeromicrobium (5 EF-Tu, 1 rpoB, 13 rpsL). The next largest phylum assigned to contigs with an ARG-like ORF was Proteobacteria, which accounted for $21 \%$ of the

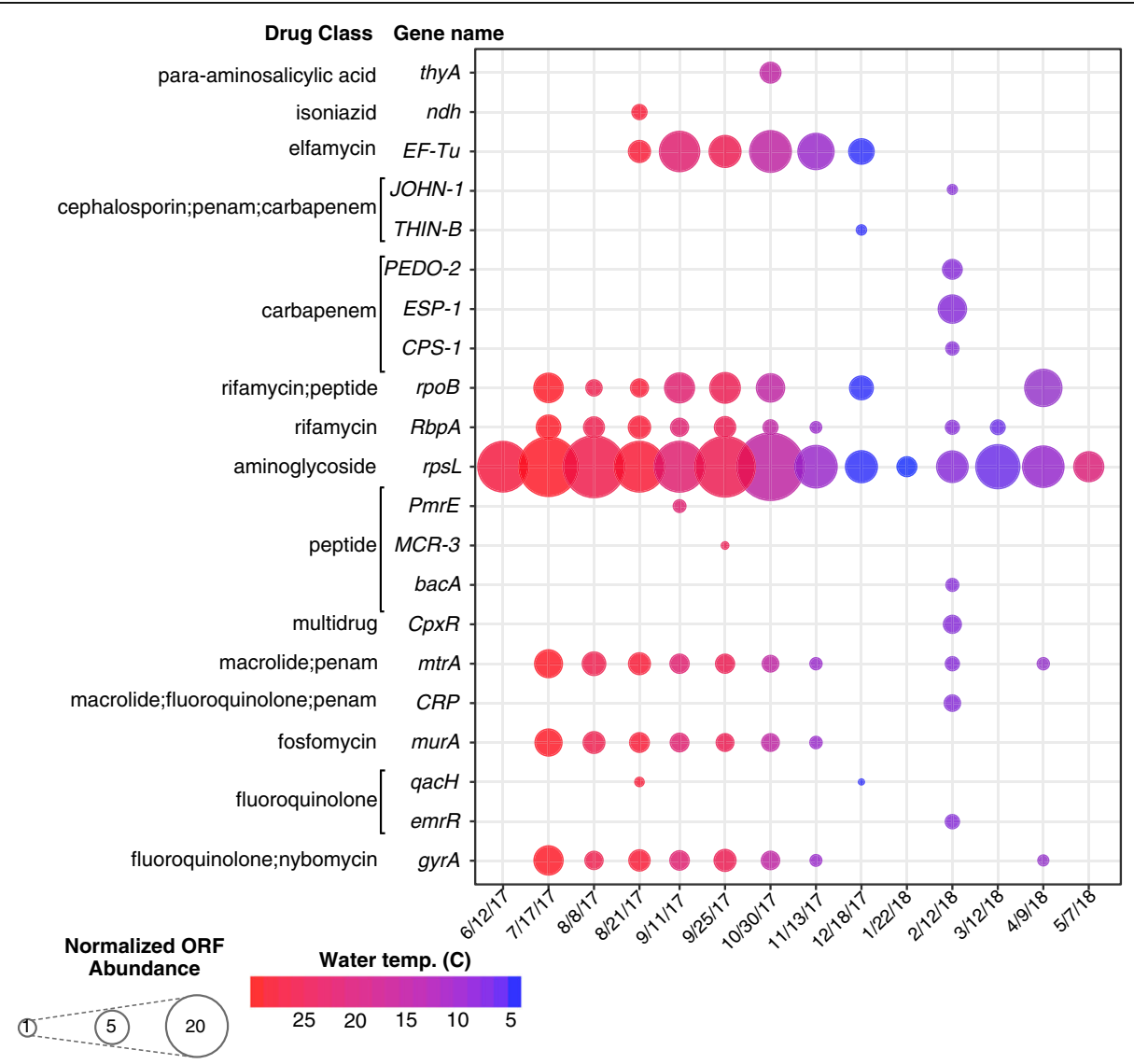

Fig. 5 Antibiotic resistance genes (ARGs) in agricultural pond water across sampling dates. Dot plot of the ARG-like translated peptide ORFs predicted from the microbial metagenomes at each sampling date. The size of each dot is equivalent to the normalized ORF abundance with homology to each ARG listed on the $y$-axis, and the color representative of the temperature of the water at the time of sampling. Normalized abundance measured as ORF coverage divided by the sum ORF coverage per million 


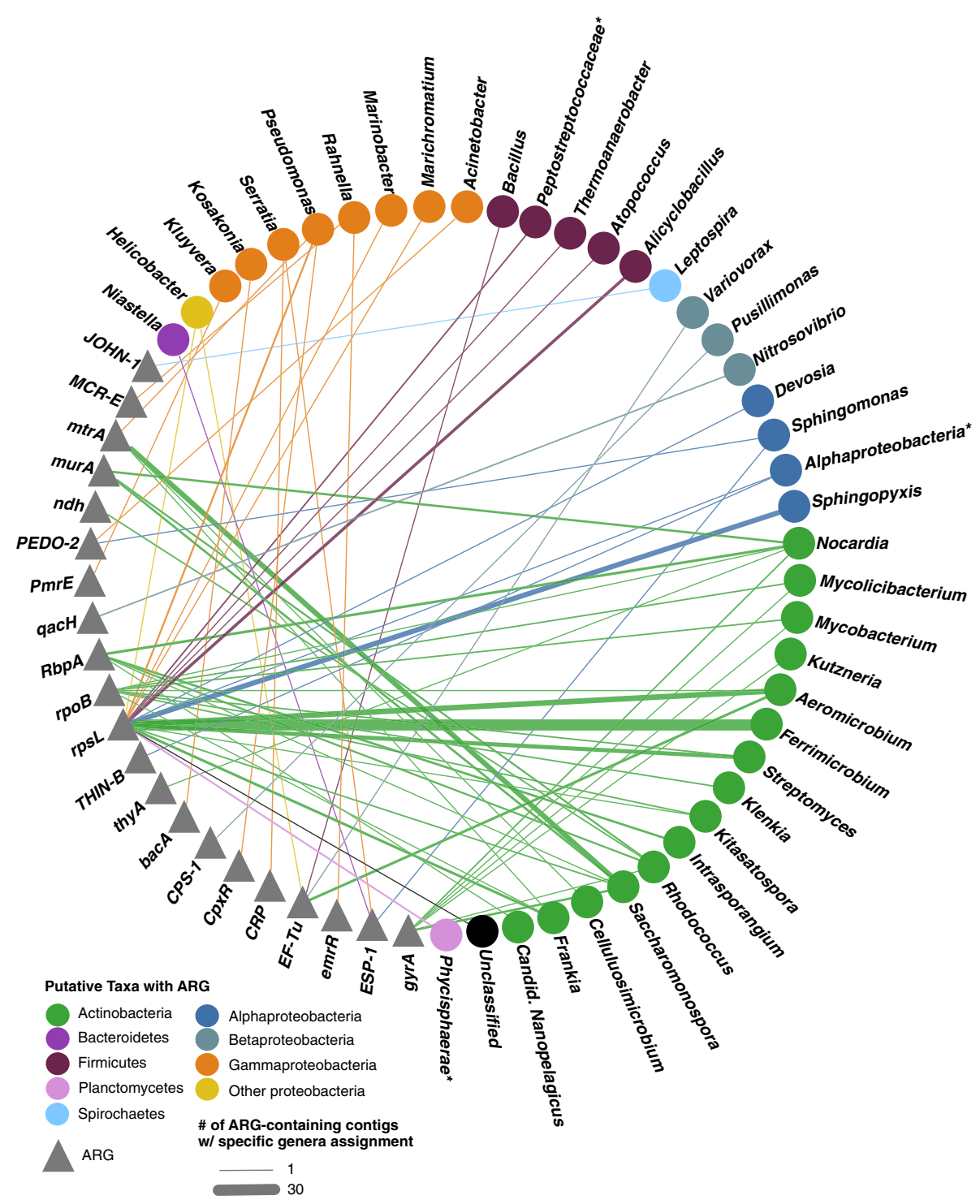

Fig. 6 ARG host network. Bipartite network of the bacterial taxa with predicted antibiotic resistance genes (ARGs). Grey triangles represent ARGs connected by an edge to its putative bacterial host, with each edge colored by the host phyla. Bacterial host defined as the taxa assigned to the contig the ARG-like translated peptide ORF originated from and colored accordingly. Asterix represent taxa that could not be assigned at the genus level

contigs, but had a wide diversity of ARGs (14 unique ARGs). Within this phylum, Sphingopyxis (12 rpsL) and Pseudomonas (3 rpsL, 1 CpxR, $1 \mathrm{mtrA}$ ) were assigned to the most contigs.

\section{Viral taxonomic and functional composition}

For the viromes, on average $47 \%$ of contigs $(+/-1 \%)$ could be assigned a taxa, which is in agreement with results described in other viral metagenomic studies [77]. For those that could be assigned, a normalized abundance was calculated. The vast majority of viral abundance was assigned to the tailed bacteriophage of the order Caudovirales (Fig. 7). Of these, the majority were similar to members of the Siphoviridae (49\% $+/-4 \%)$ family, followed by the Myoviridae $(34 \%+/-$ $5 \%)$ and Podoviridae families $(14 \%+/-2 \%)$. The remaining portion were either viral contigs that could not be assigned a family $(2 \%+/-0.1 \%)$ or were other viral families $(1 \%+/-0.2 \%)$. The other viral families included viruses infecting other bacteria and archaea, ssDNA bacteriophage Microviridae and Inoviridae, plant viruses from the family Tymoviridae, and ani$\mathrm{mal} /$ arthropod viruses from the family Poxviridae.

On average, only $10 \%(+/-2 \%)$ of translated peptide ORFs from the viromes could be assigned at a SEED system (Fig. S1). Of these, "DNA Metabolism" was 
A

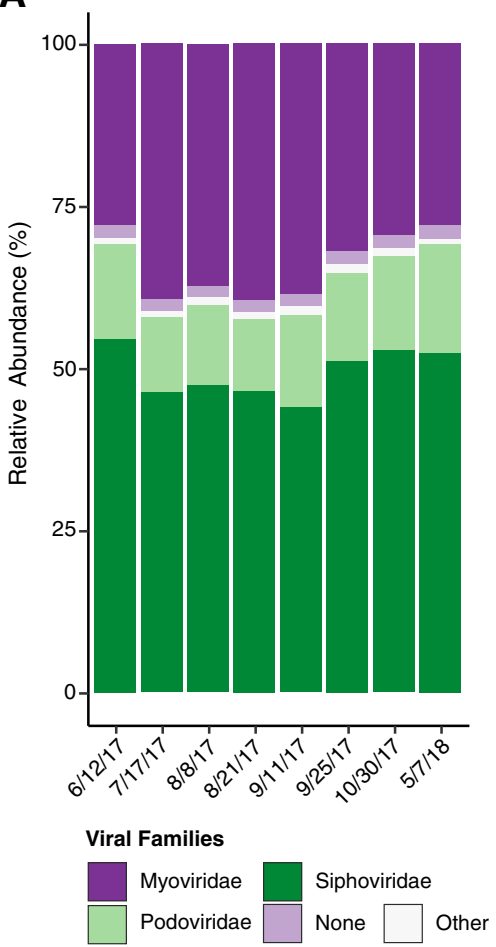

B

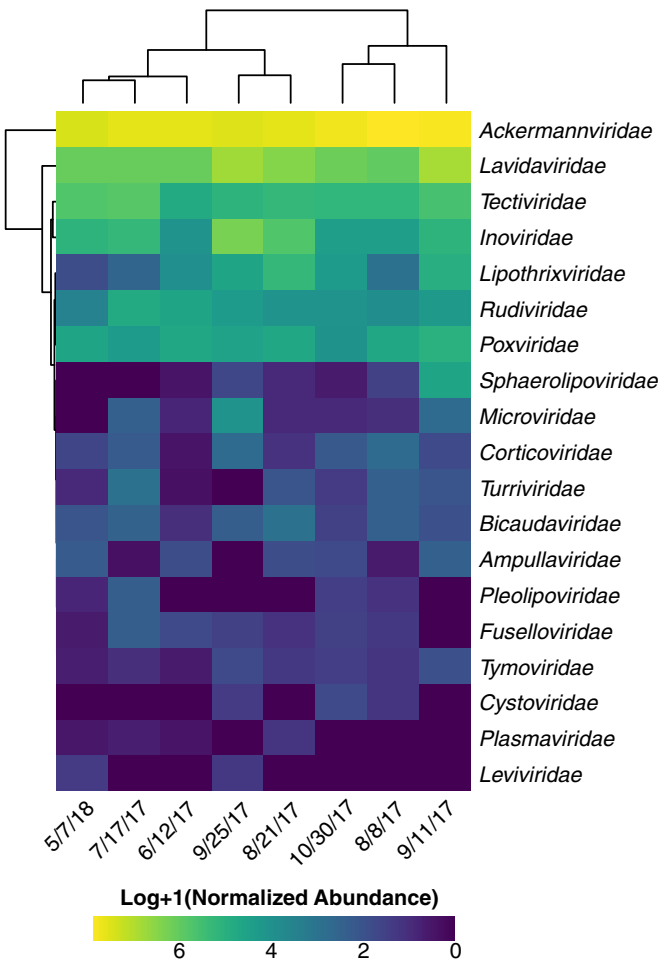

Fig. 7 Viral composition in agricultural pond water across sampling dates. (a) Stacked bar charts depicting the composition of the viral communities at the family level. Normalized abundance measured as contig coverage divided by the sum contig coverage per million and presented as a percentage. (b) Heatmap based on the (log+ 1)-transformed normalized abundance of "other" viral families. Hierarchical clustering of samples and viral taxa were performed using the complete clustering method with Euclidean distances

the most abundant representing on average $23 \%$ $(+/-5 \%)$ of the total assigned functional abundance followed by "Phages, Prophages, Transposable elements" at $12 \%(+/-0.3 \%)$, "Motility and Chemotaxis" at $9 \%(+/-1 \%)$, and "Protein Metabolism" at $7 \%$ $(+/-1 \%)$. For the dominant viral phyla we did not calculate any significant correlations between their relative abundance or functional potential and the physicochemical properties of the pond water, likely due to the limited sample size $(n=8)$.

\section{Discussion}

Freshwater is a finite natural resource essential to life on Earth. It is critical in supporting urban, agricultural, and industrial activities, as well as providing a home for a rich diversity of macro- and micro- organisms [1-6]. Yet, anthropogenic activities, climate change, and a growing global population threaten its quality and availability worldwide [78, 79]. Here, we focused our attention on one freshwater resource, ponds, that have been historically disregarded in favor of studies on larger aquatic systems.

In this study, the pond freshwater was dominated by Proteobacteria, largely that of Betaproteobacteria, a class found ubiquitously in freshwater [80]. This agrees with initial freshwater samples collected along Indian Pond in New York U.S., as well as a recent study from our lab surveying the microbial composition in a freshwater creek [81, 82]. However, here we were able to detect seasonal changes in the abundance of the bacterial phyla that corresponded to environmental conditions. For instance, during the summer months, the abundance of Cyanobacteria, increased with increasing ambient water temperature (Figs. 2 and 4). This is not surprising as water temperature has been found in multiple prior studies to be predictors of the abundance of Cyanobacteria [83, 84]. Moreover, these results agree with those reported in an earlier study from our lab, where we found, through $16 \mathrm{~S}$ rRNA gene sequencing, that the relative abundance of Cyanobacteria and Synechococcus decreased significantly with declining temperature [6]. In this study, Cyanobacteria peaked in the summer season (specifically on $7 / 17 / 17$ ), but continued at high abundance into autumn, where mild temperatures likely sustained their growth. During these peak seasons, the genus Nostoc was the most abundant within the Cyanobacteria phylum (Fig. 3). 
The Nostoc genus includes a highly diverse range of nitrogen-fixing species, commonly found in aquatic environments as either free-living, engaged in cooperative growth on plants and fungi, or in gelatinous colonies on rocks and stones [85]. While Nostoc blooms in freshwater ponds and lakes are often just considered a nuisance, there are still concerns with regard to recreational use or agricultural irrigation post and during a bloom $[86,87]$. Nostoc spp. are becoming increasingly recognized for their role in the production of cyanotoxins, as well as other bioactive compounds that can cause serious health problems in humans and animals [86, 87]. In fact, Nostoc is reported by the EPA as one of the eight most common microcystin-producing Cyanobacteria [88]. In humans, microcystin exposure is associated with both acute health effects (e.g. abdominal pain, headache, diarrhea, pneumonia, etc.) and chronic conditions (e.g. primary liver cancer, colon and rectum carcinomas) [89, 90]. While we do not know from the data presented in this study if the Nostoc spp. are toxin-producing, their persistence in the summer months is cause for future investigation to protect environmental and public health.

In addition to fluctuations driven by seasonal trends, we saw a large shift in the bacterial composition that correlated with a sizable precipitation event on 2/12/18 (Fig. 1). Likely, this event triggered an influx of upland runoff into the pond, resulting in an increase in bacterial diversity, as well as an increase in the abundance of Bacteroidetes (e.g. Rudanella, Flavobacterium) and Proteobacteria (e.g. Alphaproteobacteria) (Fig. 2). Bacteroidetes are often limited in freshwater environments, likely due to their dependency on organic matter $[80,91]$. However, previous studies have found Bacteroidetes increased in abundance within freshwater creeks following storm events [92, 93]. In these studies, the authors suggested that the increase in Bacteroidetes may be a concern, as they are often indicative of human fecal and sewage material contamination $[94,95]$. In fact, they have been suggested as better alternatives to traditional fecal indicators such as E. coli or fecal coliforms [94-96]. Along with potential pathogens and a diversity of terrestrial microorganisms, runoff can also introduce upland pollutants, such as antibiotics.

While antibiotics and ARGs are both naturally occurring, nonpoint and point source pollution of human and animal-derived wastes may select for an abundance that is atypical and may ultimately have repercussions for environmental and public health $[97,98]$. Freshwater environments have become established as important reservoirs for the potential maintenance and dissemination of ARGs, especially small lakes and pond [99]. These lentic bodies tend to have longer water retention times compared to lotic environments, which can result in the accumulation of antibiotics and selection for resistant bacteria [100, 101]. In this study, we identified
ARGs on all of the sampling dates conferring resistance through a wide range of mechanisms across clinical, veterinary, and agricultural antibiotics. This varied resistome may be attributed to the selective forces driven by the pond topography, environmental contributions, and the commensal bacterial community composition. Unlike other surface freshwater sites, the pond surveyed here was dominated by Streptomyces of the phylum Actinobacteria. Actinobacteria, particularly Streptomyces, produce many clinically significant antibiotics $[97,102,103]$. As a result, they can contain a wide array of ARGs for self-protection, as well as those inherited horizontally from other Actinobacteria $[104,105]$. Thus, it was not surprising to see that the majority of ARG putative hosts originated from Actinobacteria (Fig. 6).

As for the environmental contributions, the largest spike in ARG diversity was on $2 / 12 / 18$, which corresponded to a large precipitation event. Here, we saw the emergence of seven unique ARGs (JOHN-1, ESP-1, CRP, PEDO-2, CPS-1, CpxR, and bacA) conferring resistance to a broad range of clinically- relevant antibiotics, including three beta-lactamases against carbapenem. The majority of these ARGs, unlike in the other months, were identified on contigs assigned as Gammaproteobacteria. This is consistent with the idea that these ARGs were introduced by an influx of upland runoff, as Gammaproteobacteria are not common in freshwater and are thought to be transient members introduced from the surrounding environment [80].

While other studies on freshwater have identified phage-encoded ARGs we did not observe any ARGs in the viral fraction $[106,107]$. However, we did identify other putative functions carried largely by bacteriophages, specifically, genes related to DNA metabolism (Fig. S1). Previous studies characterizing DNA viruses in freshwater [108], wastewater treatment plants [109], and reclaimed water [110] found DNA metabolism genes were also enriched. This high abundance of viromeassociated metabolic genes suggests elevated metabolic activity within these water systems. It also highlights the potential phages in these systems have to interfere in the metabolism of their hosts [111]. This could be of particular importance within the pond surveyed here, as we also identified a large abundance of Siphoviridae, a family of largely temperate dsDNA bacteriophage. For phages, lysogeny is suggested to be advantageous when conditions are poor, such as during times of nutrientstarvation [112]. Whereas, the lytic lifestyle is suggested to dominate when the bacterial community is the most productive (e.g. summer) [113]. While we do not have viral data that spans the coldest months of the year, the abundance of Siphoviridae did decrease and the abundance of Myoviridae, a traditionally virulent phage family, did increase during the warmer months 
(7/17/17-9/11/17) surveyed. However, the dominance of phage lifestyle strategy may be more complex then previously thought, as not all studies find lysogeny to be prevalent only in times of low bacterial productivity [114]. For instance, the "piggy-back-the-winner" model was born from observations that showed lysogeny is more prevalent at higher host cell densities $[115,116]$. In this study, the prevalence of lysogenic phages may also be due to the composition of the host taxa, as the dominant bacterial phyla of the pond, Actinobacteria, and Proteobacteria, have been previously reported in some environments to be ideal hosts for temperate phages [117].

In addition to their significance as a freshwater resource for human industrial and agricultural activities, ponds are also a "hot spot" of biodiversity that significantly contribute to global ecosystem health [118]. Here, we provide one of the largest datasets on pond water microbial ecology to date. We expect these data will serve to not only improve understanding of the factors that may contribute to the disruption of pond biodiversity but also further our knowledge regarding the potential microbial risks of using pond water for agricultural irrigation.

\section{Conclusions}

Ponds represent a potential resource for freshwater, especially in agricultural settings. Here, we characterized the seasonal fluctuations in the microbial communities within one of these complex and often understudied water bodies. We found, through the use of shotgun metagenomics, that features of the bacterial community are strongly influenced by seasonal forces, including temperature, conductivity, precipitation, and turbidity. For instance, we noted that the abundance of Cyanobacteria (e.g. Nostoc spp), increased with rising ambient water temperature. In addition we characterized the functional potential of the bacterial fraction and identified 21 unique ARGs conferring resistance to over 15 drug classes, with the majority of hosts identified as members of the Actinobacteria phylum. Interestingly, we found that the diversity of ARGs, largely from Gammaproteobacterial hosts, spiked with a large precipitation event. Moreover, for a subset of samples we were able to characterize the viral communities, an often overlooked, but incredibly important, member of freshwater systems. From these data we found that Siphoviridae and Myoviridae dominated the pond, with the latter increasing during the warmer months surveyed. Taken together, these data showcase the range of compositional and functional variability within a freshwater pond over the course of a year.

\section{Supplementary information}

Supplementary information accompanies this paper at https://doi.org/10. 1186/s40793-020-00365-8.

Additional file 1: Figure S1. Functional composition in agricultural pond water viral fraction across sampling dates. Table S1. Descriptive sequencing statistics for microbial metagenomes. Table S2. Descriptive sequencing statistics for viromes. Table S3. Contig taxonomic

assignments for microbial metagenomes.

\section{Abbreviations}

CARD: Comprehensive Antibiotic Resistance Database; ARG: Antibiotic Resistance Gene; ORF: Open Reading Frame; DO: Dissolved Oxygen; ORP: Oxidation-Reduction Potential

\section{Acknowledgements}

We would also like to thank the following CONSERVE collaborators and core sampling team for supporting this work: Manan Sharma, Kali Kniel, Shirley Micallef, Fawzy Hashem, Chuck Gerba, Sadhana Ravishankar, Salina Parveen, Eric May, Amir Sapkota, Mary Theresa Callahan, Hillary Craddock, Rianna Murray, Cheryl East, Eric Handy, Prachi Kulkarni, Brienna Anderson, Shani Craighead, Samantha Gartley, Adam Vanore, Rico Duncan, Derek Foust and Joseph Haymaker.

\section{Authors' contributions}

ARS and EFM contributed to the study design, protocol development, and manuscript preparation. JC performed the majority of bioinformatic analyses, wrote and edited the manuscript. DJN and MP contributed to the data analysis. SA, JC, and AB performed the sample collection and laboratory analyses. The authors read and approved the final manuscript.

\section{Funding}

This work was supported by the United States Department of AgricultureNational Institute of Food and Agriculture, Grant number 2016-68007-25064, awarded to the University of Maryland School of Public Health, that established CONSERVE: A Center of Excellence at the Nexus of Sustainable Water Reuse, Food and Health. J.C. was supported by COMBINE, an NSF Research Traineeship program.

\section{Availability of data and materials}

Metagenomic reads were submitted to NCBI's Sequence Read Archive under the BioProject accession number PRJNA473136.

Ethics approval and consent to participate

Not applicable.

\section{Consent for publication}

Not applicable.

\section{Competing interests}

The authors declare that they have no competing interests.

\section{Author details}

${ }^{1}$ Maryland Institute for Applied Environmental Health, University of Maryland School of Public Health, College Park, MD, USA. ²Department of Pathology University of California San Diego, La Jolla, California, USA. ${ }^{3}$ Center for Bioinformatics and Computational Biology, Institute for Advanced Computer Sciences, University of Maryland, College Park, MD, USA. ${ }^{4}$ Institute for Genome Sciences and Department of Microbiology and Immunology, University of Maryland School of Medicine, Baltimore, MD, USA.

Received: 24 July 2020 Accepted: 29 September 2020

Published online: 28 October 2020

\section{References}

1. Renwick WH, Sleezer RO, Buddemeier RW, Smith SV. Small artificial ponds in the United States: impacts on sedimentation and carbon budget. In: Proceedings of the eighth Federal Interagency Sedimentation Conference; 2006. p. $738-44$ 
2. Oertli B, Biggs J, Céréghino R, Grillas $P$, Joly P, Lachavanne JB. Conservation and monitoring of pond biodiversity: introduction. Aquat Conserv Mar Freshwat Ecosyst. 2005;15(6):535-40.

3. Søndergaard $\mathrm{M}$, Jeppesen $\mathrm{E}_{1}$ Jensen JP. Pond or lake: does it make any difference? Arch Hydrobiol. 2005;162(2):143-65.

4. Davies EV, Winstanley C, Fothergill JL, James CE. The role of temperate bacteriophages in bacterial infection. FEMS Microbiol Lett. 2016;363(5):fnw015.

5. Taylor S, Gilbert P, Cooke D, Deary M, Jeffries M. High carbon burial rates by small ponds in the landscape. Front Ecol Environ. 2018;17(1):25-31.

6. Chopyk J, Allard S, Nasko DJ, Bui A, Mongodin EF, Sapkota AR. Agricultural freshwater pond supports diverse and dynamic bacterial and viral populations. Front Microbiol. 2018;9:792.

7. Biggs J, Von Fumetti S, Kelly-Quinn M. The importance of small waterbodies for biodiversity and ecosystem services: implications for policy makers. Hydrobiologia. 2017;793(1):3-39.

8. Chou W-W, Lee S-H, Wu C-F. Evaluation of the preservation value and location of farm ponds in Yunlin County, Taiwan. Int J Environ Res Public Health. 2014;11(1):548-72.

9. Biggs J, Williams $P$, Whitfield M, Nicolet $P$, Weatherby A. 15 years of pond assessment in Britain: results and lessons learned from the work of pond conservation. Aquat Conserv Mar Freshwat Ecosyst. 2005;15(6):693-714.

10. Kimbrel JA, Ballor N, Wu Y-W, David MM, Hazen TC, Simmons BA, et al. Microbial community structure and functional potential along a hypersaline gradient. Front Microbiol. 2018;9:1492.

11. Antón J, Rosselló-Mora R, Rodríguez-Valera F, Amann R. Extremely halophilic bacteria in crystallizer ponds from solar salterns. Appl Environ Microbiol. 2000;66(7):3052-7.

12. Oertli B, Joye DA, Castella E, Juge R, Cambin D, Lachavanne J-B. Does size matter? The relationship between pond area and biodiversity. Biol Conserv. 2002;104(1):59-70.

13. Crevecoeur S, Vincent WF, Comte J, Lovejoy C. Bacterial community structure across environmental gradients in permafrost thaw ponds: methanotroph-rich ecosystems. Front Microbiol. 2015;6:192.

14. Qin Y, Hou J, Deng M, Liu Q, Wu C, Ji Y, et al. Bacterial abundance and diversity in pond water supplied with different feeds. Sci Rep. 2016;6:35232.

15. Arias C, Abernathy J, Liu Z. Combined use of $16 \mathrm{~S}$ ribosomal DNA and automated ribosomal intergenic spacer analysis to study the bacterial community in catfish ponds. Lett Appl Microbiol. 2006:43(3):287-92.

16. Deng M, Hou J, Song K, Chen J, Gou J, Li D, et al. Community metagenomic assembly reveals microbes that contribute to the vertical stratification of nitrogen cycling in an aquaculture pond. Aquaculture. 2020;520:734911.

17. Boix D, Biggs J, Céréghino R, Hull AP, Kalettka T, Oertli B. Pond research and management in Europe:"small is beautiful". Hydrobiologia. 2012;689(1):1-9.

18. Kirchman DL. Processes in microbial ecology. New York: Oxford University Press; 2018.

19. Harper LR, Buxton AS, Rees HC, Bruce $K$, Brys R, Halfmaerten D, et al. Prospects and challenges of environmental DNA (eDNA) monitoring in freshwater ponds. Hydrobiologia. 2018;826(1):1-17.

20. Water M. WSUD engineering procedures: Stormwater. Melbourne: CSIRO Publishing; 2005

21. Pachepsky Y, Kierzewski R, Stocker M, Sellner K, Mulbry W, Lee H, et al. Temporal stability of Escherichia coli concentrations in waters of two irrigation ponds in Maryland. Appl Environ Microbiol. 2018;84(3):e01876-17.

22. Paerl HW, Huisman J. Blooms like it hot. Science. 2008;320(5872):57-8.

23. Mrdjen I, Fennessy S, Schaal A, Dennis R, Slonczewski JL, Lee S, et al. Tile drainage and anthropogenic land use contribute to harmful algal blooms and microbiota shifts in inland Water bodies. Environ Sci Technol. 2018;52(15):8215-23.

24. Chin DA. Linking pathogen sources to water quality in small urban streams. J Environ Eng. 2009;136(2):249-53.

25. Gu G, Luo Z, Cevallos-Cevallos JM, Adams P, Vellidis G, Wright A, et al. Factors affecting the occurrence of Escherichia coli 0157 contamination in irrigation ponds on produce farms in the Suwannee River watershed. Can J Microbiol. 2012;59(3):175-82.

26. Pandey PK, Kass PH, Soupir ML, Biswas S, Singh VP. Contamination of water resources by pathogenic bacteria. AMB Express. 2014;4(1):51.

27. Greene S, Daly E, Talbot E, Demma L, Holzbauer S, Patel N, et al. Recurrent multistate outbreak of salmonella Newport associated with tomatoes from contaminated fields, 2005. Epidemiol Infect. 2008;136(2):157-65.

28. Zhang S, Pang S, Wang P, Wang C, Han N, Liu B, et al. Antibiotic concentration and antibiotic-resistant bacteria in two shallow urban lakes after stormwater event. Environ Sci Pollut Res. 2016;23(10):9984-92.
29. Van Hoek AH, Mevius D, Guerra B, Mullany P, Roberts AP, Aarts HJ. Acquired antibiotic resistance genes: an overview. Front Microbiol. 2011;2:203.

30. Brookes JD, Antenucci J, Hipsey M, Burch MD, Ashbolt NJ, Ferguson C. Fate and transport of pathogens in lakes and reservoirs. Environ Int. 2004;30(5): 741-59.

31. Sharpton TJ. An introduction to the analysis of shotgun metagenomic data. Front Plant Sci. 2014;5:209.

32. Wommack KE, Nasko DJ, Chopyk J, Sakowski EG. Counts and sequences, observations that continue to change our understanding of viruses in nature. J Microbiol. 2015;53(3):181-92

33. Malki K, Rosario K, Sawaya NA, Székely AJ, Tisza MJ, Breitbart M. Prokaryotic and viral community composition of Freshwater Springs in Florida. USA. Mbio. 2020:11(2):e00436-20.

34. de Cárcer DA, López-Bueno A, Pearce DA, Alcamí A. Biodiversity and distribution of polar freshwater DNA viruses. Sci Adv. 2015;1(5):e1400127.

35. Roux S, Enault F, Robin A, Ravet V, Personnic S, Theil S, et al. Assessing the diversity and specificity of two freshwater viral communities through metagenomics. PLoS One. 2012;7(3):e33641.

36. Watkins SC, Kuehnle N, Ruggeri CA, Malki K, Bruder K, Elayyan J, et al. Assessment of a metaviromic dataset generated from nearshore Lake Michigan. Mar Freshw Res. 2016:67(11):1700-8.

37. Skvortsov T, de Leeuwe C, Quinn JP, McGrath JW, Allen CC, McElarney Y, et al. Metagenomic characterisation of the viral community of Lough Neagh, the largest freshwater lake in Ireland. PLoS One. 2016;11(2):e0150361.

38. Wommack KE, Colwell RR. Virioplankton: viruses in aquatic ecosystems. Microbiol Mol Biol Rev. 2000;64(1):69-114.

39. Brüssow H, Canchaya C, Hardt W-D. Phages and the evolution of bacterial pathogens: from genomic rearrangements to lysogenic conversion. Microbiol Mol Biol Rev. 2004;68(3):560-602.

40. Wang X, Kim Y, Ma Q, Hong SH, Pokusaeva K, Sturino JM, et al. Cryptic prophages help bacteria cope with adverse environments. Nat Commun. 2010;1:147.

41. Bruder K, Maiki K, Cooper A, Sible E, Shapiro JW, Watkins SC, et al. Freshwater Metaviromics and bacteriophages: a current assessment of the state of the art in relation to Bioinformatic challenges: supplementary issue: bioinformatics methods and applications for big Metagenomics data. Evol Bioinforma. 2016;12:EBO. S38549.

42. Corinaldesi C, Tangherlini M, Dell'Anno A. From virus isolation to metagenome generation for investigating viral diversity in deep-sea sediments. Sci Rep. 2017;7(1):1-12.

43. John SG, Mendez CB, Deng L, Poulos B, Kauffman AKM, Kern S, et al. A simple and efficient method for concentration of ocean viruses by chemical flocculation. Environ Microbiol Rep. 2011;3(2):195-202.

44. Chopyk J, Chattopadhyay S, Kulkarni P, Claye E, Babik KR, Reid MC, et al. Mentholation affects the cigarette microbiota by selecting for bacteria resistant to harsh environmental conditions and selecting against potential bacterial pathogens. Microbiome. 2017:5(1):22

45. Holm JB, Humphrys MS, Robinson CK, Settles ML, Ott S, Fu L, et al. Ultrahigh-throughput multiplexing and sequencing of $>500$-base-pair amplicon regions on the Illumina HiSeq 2500 platform. MSystems. 2019;4(1): e00029-19.

46. Fadrosh DW, Ma B, Gajer P, Sengamalay N, Ott S, Brotman RM, et al. An improved dual-indexing approach for multiplexed $16 \mathrm{~S}$ rRNA gene sequencing on the Illumina MiSeq platform. Microbiome. 2014;2(1):1-7.

47. Masella AP, Bartram AK, Truszkowski JM, Brown DG, Neufeld JD. PANDAseq: paired-end assembler for illumina sequences. BMC Bioinformatics. 2012; 13(1):31.

48. Caporaso JG, Kuczynski J, Stombaugh J, Bittinger K, Bushman FD, Costello EK, et al. QIIME allows analysis of high-throughput community sequencing data. Nat Methods. 2010;7(5):335-6.

49. Rognes T, Flouri T, Nichols B, Quince C, Mahé F. VSEARCH: a versatile open source tool for metagenomics. PeerJ. 2016;4:e2584

50. Huber W, Carey VJ, Gentleman R, Anders S, Carlson M, Carvalho BS, et al. Orchestrating high-throughput genomic analysis with bioconductor. Nat Methods. 2015;12(2):115-21.

51. Paulson JN, Pop M, Bravo HC, Paulson MJN. OTU TU, biocViews bioinformatics D: package 'metagenomeSeq'; 2013.

52. Oksanen J, Kindt R, Legendre P, O'Hara B, Stevens MHH, Oksanen MJ, et al. The vegan package. Community ecology package; 2007. p. 631-7.

53. McMurdie PJ, Holmes S. Phyloseq: an R package for reproducible interactive analysis and graphics of microbiome census data; 2013. 
54. Vavrek MJ. Fossil: palaeoecological and palaeogeographical analysis tools. Palaeontol Electron. 2011;14(1):16.

55. Wickham H. ggplot2: elegant graphics for data analysis. New York: Springer Science \& Business Media; 2009. p. 224.

56. Bolger AM, Lohse M, Usadel B. Trimmomatic: a flexible trimmer for Illumina sequence data. Bioinformatics. 2014;30(15):btu170.

57. Magoč T, Salzberg SL. FLASH: fast length adjustment of short reads to improve genome assemblies. Bioinformatics. 2011;27(21):2957-63.

58. Li D, Liu C-M, Luo R, Sadakane K, Lam T-W. MEGAHIT: an ultra-fast singlenode solution for large and complex metagenomics assembly via succinct de Bruijn graph. Bioinformatics. 2015;31(10):1674-6.

59. Noguchi H, Park J, Takagi T. MetaGene: prokaryotic gene finding from environmental genome shotgun sequences. Nucleic Acids Res. 2006;34(19): 5623-30.

60. Altschul SF, Gish W, Miller W, Myers EW, Lipman DJ. Basic local alignment search tool. J Mol Biol. 1990;215(3):403-10.

61. Consortium U. The universal protein resource (UniProt) in 2010. Nucleic Acids Res. 2009;38(suppl_1):D142-8.

62. Langmead B, Salzberg SL. Fast gapped-read alignment with bowtie 2. Nat Methods. 2012;9(4):357-9.

63. Conesa A, Madrigal P, Tarazona S, Gomez-Cabrero D, Cervera A, McPherson A, et al. A survey of best practices for RNA-seq data analysis. Genome Biol. 2016:17(1):1.

64. Li H, Handsaker B, Wysoker A, Fennell T, Ruan J, Homer N, et al. The sequence alignment/map format and SAMtools. Bioinformatics. 2009;25(16):2078-9.

65. Kolde R, Kolde MR. Package 'pheatmap'; 2018.

66. McArthur AG, Waglechner N, Nizam F, Yan A, Azad MA, Baylay AJ, et al. The comprehensive antibiotic resistance database. Antimicrob Agents Chemother. 2013;57(7):AAC. 00419-3.

67. Enault F, Briet A, Bouteille L, Roux S, Sullivan MB, Petit M-A. Phages rarely encode antibiotic resistance genes: a cautionary tale for virome analyses. ISME J. 2017;11(1):237.

68. Zankari E, Hasman H, Cosentino S, Vestergaard M, Rasmussen S, Lund O, et al. Identification of acquired antimicrobial resistance genes. J Antimicrob Chemother. 2012;67(11):2640-4

69. Katoh K, Misawa K, Kuma Kl, Miyata T. MAFFT: a novel method for rapid multiple sequence alignment based on fast Fourier transform. Nucleic Acids Res. 2002;30(14):3059-66.

70. Shannon P, Markiel A, Ozier O, Baliga NS, Wang JT, Ramage D, et al. Cytoscape: a software environment for integrated models of biomolecular interaction networks. Genome Res. 2003;13(11):2498-504.

71. Ballif M, Harino P, Ley S, Coscolla M, Niemann S, Carter R, et al. Drug resistance-conferring mutations in mycobacterium tuberculosis from Madang, Papua New Guinea. BMC Microbiol. 2012;12(1):191.

72. Sulochana S, Narayanan S, Paramasivan C, Suganthi C, Narayanan P. Analysis of fluoroquinolone resistance in clinical isolates of mycobacterium tuberculosis from India. J Chemother. 2007;19(2):166-71.

73. De Smet KA, Kempsell KE, Gallagher A, Duncan K, Young DB. Alteration of a single amino acid residue reverses fosfomycin resistance of recombinant MurA from mycobacterium tuberculosis. Microbiology. 1999;145(11):3177-84.

74. Sajduda A, Brzostek A, Popławska M, Augustynowicz-Kopeć E, Zwolska Z, Niemann S, et al. Molecular characterization of rifampin-and isoniazidresistant mycobacterium tuberculosis strains isolated in Poland. J Clin Microbiol. 2004;42(6):2425-31.

75. Zuurmond A-M, Olsthoorn-Tieleman LN, de Graaf JM, Parmeggiani A, Kraal B. Mutant EF-tu species reveal novel features of the enacyloxin lla inhibition mechanism on the ribosome1. J Mol Biol. 1999;294(3):627-37.

76. Vilcheze C, Weisbrod TR, Chen B, Kremer L, Hazbón MH, Wang F, et al. Altered $\mathrm{NADH} / \mathrm{NAD}+$ ratio mediates coresistance to isoniazid and ethionamide in mycobacteria. Antimicrob Agents Chemother. 2005;49(2):708-20.

77. Krishnamurthy SR, Wang D. Origins and challenges of viral dark matter. Virus Res. 2017;239:136-42.

78. Dudgeon D, Arthington AH, Gessner MO, Kawabata ZI, Knowler DJ, Lévêque C, et al. Freshwater biodiversity: importance, threats, status and conservation challenges. Biol Rev. 2006;81(2):163-82.

79. McDonald Rl, Green P, Balk D, Fekete BM, Revenga C, Todd M, et al. Urban growth, climate change, and freshwater availability. Proc Natl Acad Sci. 2011;108(15):6312-7.

80. Newton RJ, Jones SE, Eiler A, McMahon KD, Bertilsson S. A guide to the natural history of freshwater lake bacteria. Microbiol Mol Biol Rev. 2011; 75(1):14-49.
81. Zhang D, Zhang W, Liang Y. Bacterial community in a freshwater pond responding to the presence of perfluorooctanoic acid (PFOA). Environ Technol. 2019;9:1-11.

82. Chopyk J, Nasko DJ, Allard S, Callahan MT, Bui A, Ferelli AMC, et al. Metagenomic analysis of bacterial and viral assemblages from a freshwater creek and irrigated field reveals temporal and spatial dynamics. Sci Total Environ. 2020;706:135395.

83. Cha $Y$, Cho $\mathrm{KH}$, Lee $\mathrm{H}$, Kang $\mathrm{T}$, Kim JH. The relative importance of water temperature and residence time in predicting cyanobacteria abundance in regulated rivers. Water Res. 2017;124:11-9.

84. Beaulieu M, Pick F, Gregory-Eaves I. Nutrients and water temperature are significant predictors of cyanobacterial biomass in a 1147 lakes data set. Limnol Oceanogr. 2013;58(5):1736-46.

85. Dodds WK, Gudder DA, Mollenhauer D. The ecology of Nostoc. J Phycol. 1995;31(1):2-18.

86. Kurmayer R. The toxic CYANOBACTERIUM NOSTOC SP. strain 152 produces highest amounts of microcystin and NOSTOPHYCIN under stress conditions 1. J Phycol. 2011;47(1):200-7.

87. Oudra B, Dadi-El Andaloussi M, Vasconcelos V. Identification and quantification of microcystins from a Nostoc muscorum bloom occurring in Oukaïmeden River (high-atlas mountains of Marrakech, Morocco). Environ Monit Assess. 2009;149(1-4):437-44.

88. Nutrient Policy and Data: Health and Ecological Effects. https://www.epa. gov/nutrient-policy-data/health-and-ecological-effects. Accessed Jan 2019.

89. Ueno $Y$, Nagata S, Tsutsumi T, Hasegawa A, Watanabe MF, Park H-D, et al. Detection of microcystins, a blue-green algal hepatotoxin, in drinking water sampled in Haimen and Fusui, endemic areas of primary liver cancer in China, by highly sensitive immunoassay. Carcinogenesis. 1996;17(6):1317-21.

90. Lun Z, Hai Y, Kun C. Relationship between microcystin in drinking water and colorectal cancer. Biomed Environ Sci. 2002;15(2):166-71.

91. Eiler A, Bertilsson S. Flavobacteria blooms in four eutrophic lakes: linking population dynamics of freshwater bacterioplankton to resource availability. Appl Environ Microbiol. 2007;73(11):3511-8.

92. Ulrich N, Rosenberger A, Brislawn C, Wright J, Kessler C, Toole D, et al. Restructuring of the aquatic bacterial community by hydric dynamics associated with superstorm sandy. Appl Environ Microbiol. 2016:82(12):3525-36.

93. Kan J. Storm events restructured bacterial community and their biogeochemical potentials. J Geophys Res Biogeo. 2018;123(7):2257-69.

94. Layton A, McKay L, Williams D, Garrett V, Gentry R, Sayler G. Development of Bacteroides 165 rRNA gene TaqMan-based real-time PCR assays for estimation of total, human, and bovine fecal pollution in water. Appl Environ Microbiol. 2006:72(6):4214-24.

95. Fiksdal L, Maki J, LaCroix S, Staley J. Survival and detection of Bacteroides spp., prospective indicator bacteria. Appl Environ Microbiol. 1985;49(1):148-50.

96. Dick LK, Bernhard AE, Brodeur TJ, Santo Domingo JW, Simpson JM, Walters SP, et al. Host distributions of uncultivated fecal Bacteroidales bacteria reveal genetic markers for fecal source identification. Appl Environ Microbiol. 2005;71(6):3184-91.

97. D'Costa VM, King CE, Kalan L, Morar M, Sung WW, Schwarz C, et al. Antibiotic resistance is ancient. Nature. 2011;477(7365):457.

98. Levy SB, Marshall B. Antibacterial resistance worldwide: causes, challenges and responses. Nat Med. 2004;10(12s):S122.

99. Marti E, Variatza E, Balcazar JL. The role of aquatic ecosystems as reservoirs of antibiotic resistance. Trends Microbiol. 2014;22(1):36-41.

100. Yang $Y$, Song $W$, Lin H, Wang W, Du L, Xing W. Antibiotics and antibiotic resistance genes in global lakes: a review and meta-analysis. Environ Int. 2018;116:60-73.

101. Czekalski N, Sigdel R, Birtel J, Matthews B, Bürgmann H. Does human activity impact the natural antibiotic resistance background? Abundance of antibiotic resistance genes in 21 Swiss lakes. Environ Int. 2015;81:45-55.

102. Watve MG, Tickoo R, Jog MM, Bhole BD. How many antibiotics are produced by the genus Streptomyces? Arch Microbiol. 2001;176(5):386-90.

103. Bhullar K, Waglechner N, Pawlowski A, Koteva K, Banks ED, Johnston MD, et al. Antibiotic resistance is prevalent in an isolated cave microbiome. PLoS One. 2012;7(4):e34953

104. Thaker MN, Wang W, Spanogiannopoulos P, Waglechner N, King AM, Medina R, et al. Identifying producers of antibacterial compounds by screening for antibiotic resistance. Nat Biotechnol. 2013;31(10):922.

105. Egan S, Wiener P, Kallifidas D, Wellington E. Phylogeny of Streptomyces species and evidence for horizontal transfer of entire and partial antibiotic gene clusters. Antonie Van Leeuwenhoek. 2001;79(2):127-33. 
106. Balcazar JL. Bacteriophages as vehicles for antibiotic resistance genes in the environment. PLoS Pathog. 2014;10(7):e1004219.

107. Moon K, Jeon JH, Kang I, Park KS, Lee K, Cha C-J, et al. Freshwater viral metagenome reveals novel and functional phage-borne antibiotic resistance genes. Microbiome. 2020;8(1):1-15.

108. Dinsdale EA, Edwards RA, Hall D, Angly F, Breitbart M, Brulc JM, et al. Functional metagenomic profiling of nine biomes. Nature. 2008;452(7187): 629.

109. Tamaki H, Zhang R, Angly FE, Nakamura S, Hong PY, Yasunaga T, et al. Metagenomic analysis of DNA viruses in a wastewater treatment plant in tropical climate. Environ Microbiol. 2012;14(2):441-52

110. Chopyk J, Kulkarni P, Nasko DJ, Bradshaw R, Kniel KE, Chiu P, et al. Zerovalent iron sand filtration reduces concentrations of virus-like particles and modifies virome community composition in reclaimed water used for agricultural irrigation. BMC Res Notes. 2019;12(1):223.

111. Segobola J, Adriaenssens E, Tsekoa T, Rashamuse K, Cowan D. Exploring viral diversity in a unique south African soil habitat. Sci Rep. 2018:8(1):111.

112. Williamson S, Houchin L, McDaniel L, Paul J. Seasonal variation in lysogeny as depicted by prophage induction in Tampa Bay. Florida. Appl Environ Microbiol. 2002;68(9):4307-14.

113. Payet JP, Suttle CA. To kill or not to kill: the balance between lytic and lysogenic viral infection is driven by trophic status. Limnol Oceanogr. 2013, 58(2):465-74.

114. Lara E, Vaqué D, Sà EL, Boras JA, Gomes A, Borrull E, et al. Unveiling the role and life strategies of viruses from the surface to the dark ocean. Sci Adv. 2017;3(9):e1602565.

115. Knowles B, Silveira C, Bailey B, Barott K, Cantu V, Cobián-Güemes A, et al. Lytic to temperate switching of viral communities. Nature. 2016;531(7595): 466.

116. Silveira CB, Rohwer FL. Piggyback-the-winner in host-associated microbial communities. NPJ Biofilms Microbiomes. 2016;2:16010.

117. Costeira R, Doherty R, Allen CC, Larkin MJ, Kulakov LA. Analysis of viral and bacterial communities in groundwater associated with contaminated land. Sci Total Environ. 2019;656:1413-26.

118. Hill MJ, Hassall C, Oertli B, Fahrig L, Robson BJ, Biggs J, et al. New policy directions for global pond conservation. Conserv Lett. 2018;11(5):e12447.

\section{Publisher's Note}

Springer Nature remains neutral with regard to jurisdictional claims in published maps and institutional affiliations.

Ready to submit your research? Choose BMC and benefit from:

- fast, convenient online submission

- thorough peer review by experienced researchers in your field

- rapid publication on acceptance

- support for research data, including large and complex data types

- gold Open Access which fosters wider collaboration and increased citations

- maximum visibility for your research: over $100 \mathrm{M}$ website views per year

At $\mathrm{BMC}$, research is always in progress.

Learn more biomedcentral.com/submissions 